\title{
DAYA TARIK WISATA, PROMOSI MEDIA SOSIAL, DAN REFERENCES GROUP TERHADAP KEPUTUSAN BERKUNJUNG KE DE TJOLOMADOE KABUPATEN KARANGANYAR
}

\author{
Ferintika Priyanti, Istiqomah, Ida Aryati \\ Fakultas Ekonomi Universitas Islam Batik Surakarta \\ Email:ferintika1234@gmail.com
}

\begin{abstract}
The purpose of this study was to analyze the influence of whether or not the Tourism Attraction, Social Media Promotion, and Group References Against the Decision to Visit De Tjolomadoe Karanganyar Regency. The population in this study were all visitors of De Tjolomadoe Karanganyar Regency whose number was 4,543 visitors in August - October 2019. The sampling technique was an infinite number using the Slovin formula, with a total of 100 respondents. Data collection uses a Likert scale questionnaire to measure respondents' answers identifying the relationship between tourist attraction, social media promotion, and group references to decisions. The results show that tourist attraction, promotion of social media, and reference groups simultaneously and significantly influence the decision to visit at De Tjolomadoe Karanganyar, Central Java. The tourist attraction has a positive and significant effect on the decision to visit at De Tjolomadoe Karanganyar, Central Java. The promotion of social media has a positive and significant impact on the decision to visit at De Tjolomadoe Karanganyar, Central Java. References group has a positive and significant effect on the decision to visit at De Tjolomadoe Karanganyar, Central Java.
\end{abstract}

Keyword :Travel attractions, social media promotion, reference groups, decisions

\begin{abstract}
Abstrak : Tujuan dari penelitian ini adalah untuk menganalisis berpengaruh atau tidaknya Daya Tarik Wisata, Promosi Media Sosial, Dan References Group Terhadap Keputusan Berkunjung Ke De Tjolomadoe Kabupaten Karanganyar. Populasi didalam penelitian ini adalah seluruh pengunjung De Tjolomadoe Kabupaten Karanganyar yang jumlahnya 4.543 pengunjung pada bulan Agustus - Oktober 2019.Teknik pengambilan sampel tersebut adalah jumlah tak terhingga menggunakan rumus slovin, dengan jumlah 100 responden.Data pengumpulan menggunakan kuesioner skala likert untuk mengukur jawaban responden mengidentifikasi hubungan antara daya tarik wisata, promosi media sosial, dan references group terhadap keputusan.Hasilnya yaitu menunjukkan bahwa Daya tarik wisata, promosi media sosial, dan references group berpengaruh secara simultan dan signifikan terhadap keputusan berkunjung di De Tjolomadoe Karanganyar Jawa Tengah.Daya tarik wisata berpengaruh positif dan signifikan terhadap keputusan berkunjung di De Tjolomadoe Karanganyar Jawa Tengah.Promosi media sosial berpengaruh positif dan signifikan terhadap keputusan berkunjung di De Tjolomadoe Karanganyar Jawa Tengah.References group berpengaruh positif dan signifikan terhadap keputusan berkunjung di De Tjolomadoe Karanganyar Jawa Tengah.
\end{abstract}

Kata Kunci: Daya tarik wisata, promosi media sosial, references group, keputusan. 


\section{PENDAHULUAN}

Perkembangan industri pariwisata di Indonesia berkembang sangat pesat bahkan banyak yang dijadikan sebagai gaya hidup oleh masyarakat Indonesia. Pariwisata juga dapat membantu perekonomian masyarakat disekitar tempat wisata sehingga pertumbuhan ekonomi daerah dapat meningkat.

Smallman dan Moore (2010), keputusan berkunjung merupakan kegiatan yang kompleks terjadi dan melalui proses panjang, keputusan muncul dari rasa ingin tahu akan obyek wisata, tindakan yang dilakukan wisatawan mulai dari memilih tempat, proses pencarian informasi sampai pada waktu berkunjung. Lapian (2015), keputusan berkunjung menjadikan salah satu dari keberhasilan suatu pemasaran, dimana tujuan pemasaran memberi keuntungan atau laba bagi perusahaan.

Rindani (2016), Daya tarik pariwisata harus mempunyai empat komponen yaitu attration (atraksi), accessibilities (aksesbilitas), amenities (fasilitas) dan ancillary service (jasa pendukung pariwisata).kegiatan promosi pariwisata sangatlah bermanfaat bagi memperkenalkan objek wisata daerah dan menarik pengunjung untuk minat berkunjung.

Lewis (2016), media sosial merupakan teknologi digital yang memungkinkan pmanusia untuk saling berinteraksi, dan berbagai isi pesan Facebook, Path, Twitter, Line, Whatsapp, Instagram merupakan beberapa media sosial yang dapat digunakan untuk dapat berkomunikasi.

Abyad (2017), bahwa media internet memberikan keuntungan dalam melakukan komunikasi pemasaran dalam berbagai bidang karena dengan media internet konsumen diberikan kemudahan dalam mencari dan memperoleh barang yang diinginkan selain itu sebagai alat penyebar informasi.

Reza dan Valeecha (2013), didunia nyata, keluarga, teman kerja, sahabat, saudara, dan pengalaman seseorang juga merupakan bagian dari kelompok acuan. Kelompok - kelompok ini berlaku menjadi titik referensi yang dapat mempengaruhi seseorang dalam melakukan keputusan pembelian.

Dari hasil uraian diatas peneliti layak untuk penelitian dengan judul Daya Tarik Wisata, Promosi Media Sosial dan References Grouppterhadap keputusan berkunjung ke De Tjolomadoe Kabupaten Karanganyar.

\section{TINJAUAN PUSTAKA}

\section{Keputusan Berkunjung}

Keputusan berkunjung adalah sebuah kegiatan yang dilakukan oleh seseorang atau sekelompok orang dengan mengunjungi tempat tertentu untuk tujuan rekreasi, pengembangan pribadi, atau mempelajari keunikan daya tarik wisata yang dikunjungi dalam jangka waktu sementara Juwita p(2016: 206). Swastha dan Handoko (2012: 15) menyatakan keputusan pembelian adalah pendekatan penyelesaian masalah pada kegiatan manusia untuk membeli suatu barang atau jasa dalam memenuhi keinginan, pencarian informasi, evaluasi terhadap alternatif pembeli, keputusan pembelian dan tingkah laku setelah pembelian. Berdasarkan dari beberapa pendapat diatas menurut penulis keputusan berkunjung atau pembelian adalah perilaku seseorang dalam memenuhi keinginan atau menentukan suatu pilihan tempat tertentu untuk mencapai kepuasan.

Terdapat faktor - faktor pyang dapat mempengaruhi keputusan pembelian konsumen (Kotler dan Keller, 2012: 160)
a. Faktor kebudayaan.
b. Faktor social.
c. Keputusan seorang pembeli. 


\section{d. Pilihan pembeli seseorang.}

\section{Daya Tarik Wisata}

Undang-Undang Republik Indonesia Nomor 10.Tahun 2009 Tentang Kepariwisataan, Daya tarik wisata adalah segala sesuatu yang pmemiliki keunikan, keindahan, dan nilai yang berupa keanekaragaman kekayaan alam, budaya, dan hasil buatan manusia yang menjadi sasaran atau tujuan kunjungan wisatawan.

Spillane (2002), Daya tarik pariwisata adalah hal-hal yang menarik perhatian wisatawan yang dimiliki oleh suatu daerah tujuan wisata. Dari beberapa pengertian diatas daya tarik wisata adalah hal-hal yang menarik perhatian wisatawan yang dimiliki oleh suatu daerah atau tempat tujuan wisata.

Dengan 5 unsur penting dalam suatu destinasi wisata, yaitu:

a. Berbagai hal yang menarik perhatian wisatawan (Attraction)

b. Fasilitas-fasilitas yang diperlukan (Facilities)

c. Infrastruktur dari objek wisata (Infrastructure)

d. Jasa-jasa transportasi (Transportation)

e. Keramahtamahan dalam menerima tamu (Hospitality)

\section{Promosi Media Sosial}

Kotler dan Keller (2012; 498) komunikasi pemasaran adalah sarana yang digunakan untuk menginformasikan, membujuk,dan mengingatkan konsumen baik secara langsung maupun tidak langsung tentang produk dan merek yang mereka jual.

Mila Setiawan (2015) menyebutkan media sosial merupakan alat promosi bisnis yang efektif karena dapat diakses oleh siapa saja, sehingga jaringan promosi bisa lebih luas. Media sosial menjadi bagian yang sangat diperlukan oleh pemasaran bagi banyak perusahaan dan merupakan salah satu cara terbaik untuk menjangkau pelanggan dan klien.

\section{Reference Group}

Sumarwan (2011: 305) kelompok referensi (references group) adalah seorang individu atau kelompok yang secara nyata mempengaruhi perilaku seorang. Kelompok referensi melibatkan satu orang atau lebih yang digunakan sebagai alasan pembandingan atau acuan dalam membentuk respon afektif dan respon kognitif serta perilaku. Yuniarti (2015:206) kelompok acuan adalah seorang individu atau kelompok orang yang secara nyata mempengaruhi perilaku seorang.Kelompok acuan menjadi dasar yang digunakan seorang sebagai perbandingan atau acuan dalam membentuk respon afektif, kognitif, dan perilaku. Kelompok acuan merupakan suatu kelompok orang yang mempengaruhi sikap, pendapat, norma dan perilaku konsumen.

\section{METODOLOGI PENELITIAN}

Penelitian ini menggunakan data primer yang diperoleh dari pengunjung De Tjolomadoe Kabupaten Karanganyar. Teknik pengambilan sample yang digunakan adalah pjumlah tak pterhingga pmenggunakan prumus pslovin, dengan pjumlah 100 presponden. Metode analisis data yang digunakan antara lain: uji instrument (validitas dan reliabilitas ), puji pasumsi pklasik, uji hipotesis ( analisis regresi linier berganda, uji t, puji $\mathrm{F}$, dan koefisien determinasi $\left(\mathrm{R}^{2}\right)$ 


\section{Hipotesis}

Hipotesis dalam penelitian ini adalah:

1) Daya Tarik Wisata, Promosi Media Sosial dan References Group secara simultan berpengaruh terhadap keputusan berkunjung ke De Tjolomadoe Kabupaten Karanganyar.

2) DidugaDaya Tarik Wisata berpengaruh positif dan signifikan terhadap keputusan berkunjung ke De Tjolomadoe Kabupaten Karanganyar.

3) Diduga Promosi Media Sosial berpengaruh positif dan signifikan terhadap keputusan berkunjung ke De Tjolomadoe Kabupaten Karanganyar.

4) Diduga References Group berpengaruh positif dan signifikan terhadap keputusan berkunjung ke De Tjolomadoe Kabupaten Karanganyar.

\section{HASIL PENELITIAN}

Hasil analisis deskriptif menunjukan bahwa responden berjenis kelamin lakilaki (48\%) dan perempuan (52\%). Semua data dari penyebaran kuisioner telah lolos uji instrument .

Hasil uji asumsi klasik:

a. Uji Normalitas

Berdasarkan hasil perhitungan uji Kolmogorov Smirnov dapat diketahui bahwa p-value adalah 0,684. Nilai p-value ternyata lebih besar dari $\alpha$ (p>0,05), maka dapat disimpulkan sebaran datanya normal.
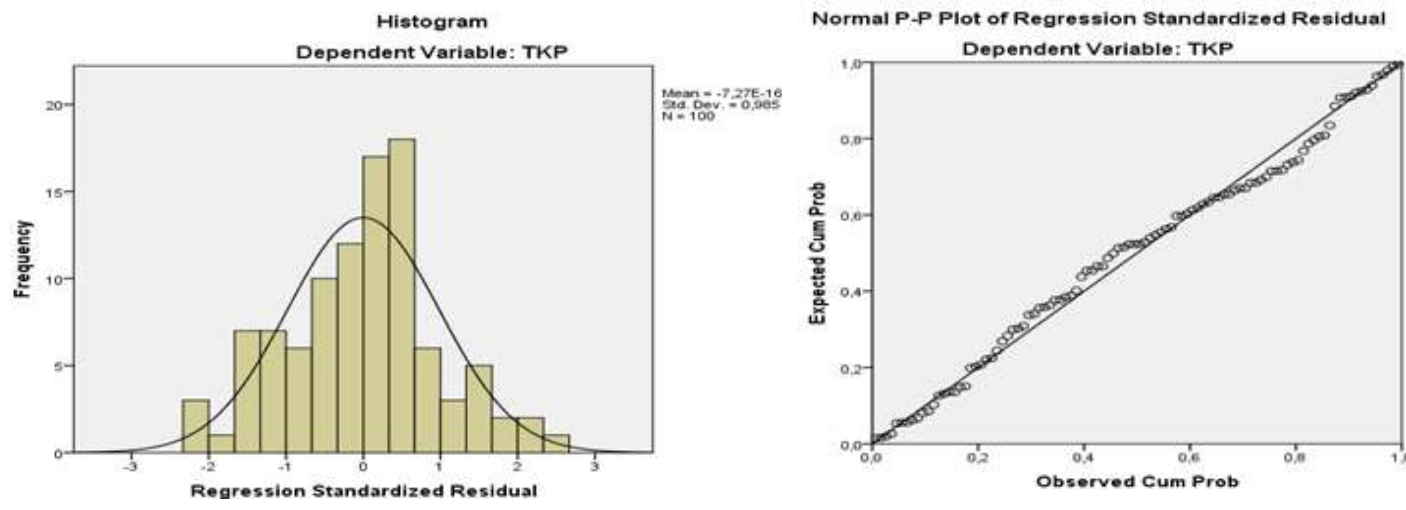

b. Uji Multikolineritas

\begin{tabular}{lccc}
\hline \multicolumn{1}{c}{ Model } & \multicolumn{2}{c}{$\begin{array}{c}\text { Collinearity Statistics } \\
\text { Tolerance }\end{array}$} & VIF \\
\hline $\begin{array}{l}\text { Daya tarik } \\
\text { wisata }\end{array}$ & .819 & 1.112 & Keterangan \\
$\begin{array}{l}\text { Promosi media } \\
\text { social }\end{array}$ & .893 & 1.120 & Tidak terjadi multikolinearitas \\
Reference group & .791 & 1.009 & $\begin{array}{l}\text { Tidak terjadi multikolinearitas } \\
\text { Tidak terjadi multikolinearitas }\end{array}$ \\
\hline
\end{tabular}

Berdasarkan tabel diatas dapat disimpulkan bahwa model regresi tersebut tidak terjadi multikolineritas karena nilai $\mathrm{VIF}<10$ dan Toleransi $>0,1$. 
c. Uji Hesteroskedastisitas

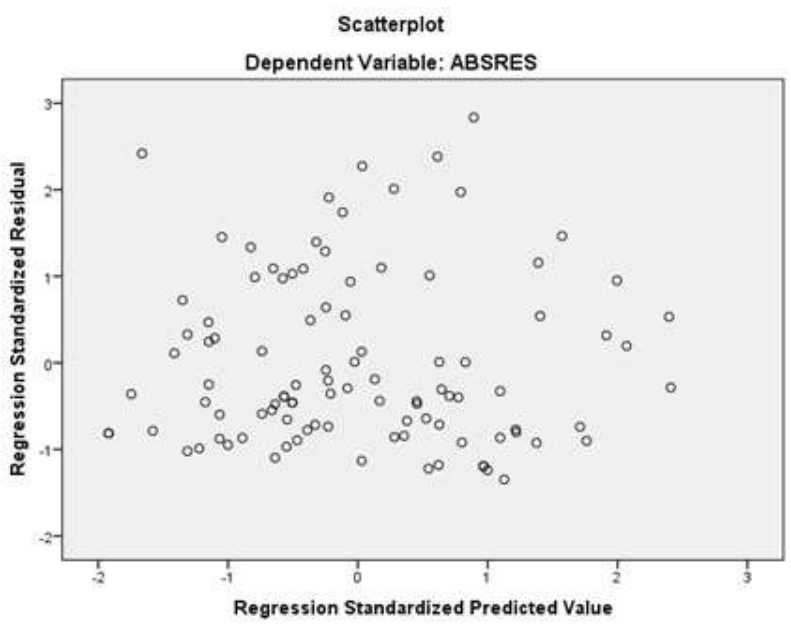

Berdasarkan tabel diatas menunjukan bahwa titik-titik tersebut berada diatas dan dibawah nilai 0 . Hasil tersebut menunjukkan bahwa tidak terjadi adanya heteroskedastisitas.

Untuk pengujian uji $f$ diperoleh hasil bahwa nilai $F_{\text {hitung }}(20,655)>F_{\text {tabel }}$ $(3,15)$ dengan probabilitas sebesar $0,000(\mathrm{p}<0,05)$. Hal ini menunjukkan $\mathrm{F}$ hitung berada pada daerah Ho ditolak artinya terdapat pengaruh simultan dan signifikan dari daya tarik wisata, promosi media sosial, dan references group terhadap keputusan berkunjung pada De Tjolomadoe Karanganyar. Model persamaan regresi disusun sebagai berikut:

$$
\mathrm{Y}=2,415+0,346 X_{1}+0,377 X_{2}+0,305 X_{3}+\mathrm{e}
$$

Dari hasil uji $\mathrm{t}$ diperoleh hasil daya tarik wisata berpengaruh positif dan simultan terhadap keputusan berkunjung. Hal ini terbukti dari nilai thitung $(1,985)<$ $\mathrm{t}_{\text {tabel }}(4,415)$ dengan nilai signifikansi $<\alpha(0,05)$. promosi media sosial berpengaruh positif dan signifikan terhadap keputusan berkunjung. Hal ini terbukti dari nilai $t_{\text {hitung }}(1,985)>t_{\text {tabel }}(3,711)$ dengan nilai signifikansi $<\alpha(0,05)$. Demikian juga references group berpengaruh positif dan signifikan terhadap keputusan berkunjung. Hal ini terbukti dari nilai $t_{\text {hitung }}(1,985)>t_{\text {tabel }}(2,960)$ dengan nilai signifikansi< $\alpha(0,05)$. Hasil analisis dalam penelitian ini menunjukkan $R^{2}$ sebesar $0,472(47,2 \%)$. Hal ini berarti daya tarik wisata, promosi media sosial dan references group mampu berkontribusi sebesar 47,2\% terhadap keputusan berkunjung. Sedangkan sisanya sebesar 52,8\% dipengaruhi oleh variabel lain diluar penelitian ini.

\section{KESIMPULAN}

Dari pembahasan dan hasil diatas, dapat ditarik beberapa kesimpulan:

1) Daya tarik wisata, promosi media sosial, dan references group berpengaruh secara simultan dan signifikan terhadap keputusan berkunjung di De Tjolomadoe Karanganyar Jawa Tengah.

2) Daya tarik wisata berpengaruh positif dan signifikan terhadap keputusan berkunjung di De Tjolomadoe Karanganyar Jawa Tengah. 
3) Promosi media sosial berpengaruh positif dan signifikan terhadap keputusan berkunjung di De Tjolomadoe Karanganyar Jawa Tengah.

4) References group berpengaruh positif dan signifikan terhadap keputusan berkunjung di De Tjolomadoe Karanganyar Jawa Tengah.

\section{SARAN}

Berdasarkan hasil penelitian, pembahasan, dan kesimpulan yang diperoleh, maka saran yang dapat diberikan adalah sebagai berikut:

1) Berdasarkan hasil penelitian ini hendaknya pihak De Tjolomadoe dapat meningkatkan fasilitas dan daya tarik wisata untuk menarik perhatian pengunjung lokal maupun manca negara.

2) Berdasarkan penelitian ini sebaiknya pengelola De Tjolomadoelebih mengembangkan promosi dibidang sosial media seperti platform instagram, facebook, dan twitter sehingga dapat menarik semua kalangan untuk lebih tertarik menjadikan De Tjolomadoe sebagai pengembangan masyarakat luas.

3) Berdasarkan hasil peneliti yang di dapatkan, seharusnya pihak pengelola lebih banyak mengadakan event-event yang dapat mengundang khalayak ramai sehingga terjadilah komunikasi internal.

4) Bagi penelitian selanjutnya untuk mengembangkan penelitian dengan variabel bebas lainnya selain daya tarik wisata, promosi media sosial dan references group seperti gaya hidup, event marketing, dan lain-lainnya. 


\section{DAFTAR PUSTAKA}

Abyad, Abdulrazag. 2017. Importance of Consumer Trust in e-commerce. Middle East Journal of Bussiness. Vol 12

Juwita dan Harivanto 2016. "Pengaruh Dava Tarik Wisata Terhadap Keputusan Berkunjung Wisatawan Nusantara." Jumal Pariwisata ( Vol.3 No.1). Hlm 20-28. STP ARS Intemasional.

Lapian. 2015. The influence of advertising and tourist attractionon tourist decision making to visit firdaus beach in north minahasa. European Journal of Business and management.

Spillane, James J. 2015. Pariwisata Indonesia Sejarah dan Prospeknya. Yogyakarta $\cdot$ Kanisius

Sekaran, Uma. (2006) Metodologi Penelitian Untuk Bisnis Buku 1 Edisi 4. Jakarta: Salemba Empat

Sugivono. 2014. Metode Penelitian Pendidikan Pendekatan Kuantitatif.

Wall 2017. Factor influencing tourist decision making towards Traveling in Luang Prabang. European Journal of Business and management

Warpani (2007). Pariwisata Dalam Tata Ruang Wilayah. Bandung: ITB

Wiraguna. I. M. I \& Pratama. I G S . (2019). Analisis Faktor-Faktor yang Mempengaruhi Keputusan Wisatawan Berkunjung ke Bali Zoo di Singapadu Gianvar Warmadewa Management and Business Journal WMBJ). $1(1), p p .45-54$.

Yuliviona 2016. Factor influencing tourists decision in visiting Mandeh Resort in West Sumatera Indonesia. European Journal of Business and management

Zen.W 2017. Dava tarik wisata dan promosi terhadap keputusan memilih objek wisata kawasan Mandeh Kabupaten Pesisir Selatan. Jumal manajemen dan kewirausahaan Vol.8 No. I Universitas Muhammadivah Ponorogo. 